24 weeks of study treatment. Improvement of median proteiuria reduction from base line was $64.2 \%$ at 12 weeks and $88 \%$ at 24 weeks. Serum vitamin D levels were inversely associated with the urinary protein creatinine UP/C ratio $(\mathrm{p}<0.001)$ and urinary vit $\mathrm{D}$ binding protein $\mathrm{DBP} / \mathrm{C}(\mathrm{p}<0.001)$.

Conclusions Our findings show that new strategy of adding vitamin $\mathrm{D}$ therapy as new treatment for 24 weeks to maintain optimal serum $25(\mathrm{OH})$ D levels and diminish proteinuria in lupus nephritis patients. We need longer duration and more studies to confirm our results from different countries.

\section{PS7:139 EFFICACY AND SAFETY OF RITUXIMAB IN RESISTANT SLE}

${ }^{1} \mathrm{R}$ Attar, ${ }^{2} \mathrm{O}$ Safdar, ${ }^{2} \mathrm{M}$ Muzaffar, ${ }^{1} \mathrm{~S}$ Attar, ${ }^{3} \mathrm{M}$ Alhomeid. ${ }^{1}$ Department on internal medicine, King Abdulaziz University Hospital, Jeddah, Saudi Arabia; ${ }^{2}$ Department of paediatric, Faculty of medicine, King Abdulaziz University, Jeddah, Saudi Arabia; ${ }^{3}$ College of medicine, King Abdulaziz University, Jeddah, Saudi Arabia

\subsection{6/lupus-2018-abstract.182}

Objective Rituximab is a B cell depleting monoclonal antiCD20 antibody that has been suggested by number of research as a potential Effective agent in Resistant active SLE. however, related clinical trials; 'Explorer', 'lunar' trials both failed to show clinically significant efficacy of Rituximab compared to placebo.In this uni-centre study, we evaluated the Efficacy and safety of Rituximab in refractory SLE patients.

\begin{tabular}{|c|c|}
\hline \multicolumn{2}{|l|}{ Age } \\
\hline mean $\pm \mathrm{SD}$ years & $28.6 \pm 15.2$ \\
\hline mean pediatric $\pm S D$ & $14.3 \pm 3.1$ \\
\hline mean adult $\pm \mathrm{SD}$ & $33.7 \pm 14.4$ \\
\hline Disease duration, mean \pm SD years & $4.2 \pm 3.8$ \\
\hline \multicolumn{2}{|l|}{ Main indication for rituximab \% (n) } \\
\hline Renal (Lupus nephritis) & $26.1(6)$ \\
\hline Hematological & $21.7(5)$ \\
\hline Neuropsychiatric & $30.4(7)$ \\
\hline Cutaneous & $13.0(3)$ \\
\hline Lupus nephritis/ hematological (pancytopenia) & $8.6(2)$ \\
\hline \multicolumn{2}{|l|}{ Disease activity before rituximab } \\
\hline SLEDAI score, mean \pm SD years & $15.0 \pm 8.8$ \\
\hline Anti-DNA antibody, $\%(\mathrm{n})$ & $78.3(18)$ \\
\hline $\mathrm{C} 3$, mean $\pm \mathrm{SD} g / \mathrm{L}$ & $0.66 \pm 0.34$ \\
\hline $\mathrm{C} 4$, mean $\pm \mathrm{SD} \mathrm{g} / \mathrm{L}$ & $0.12 \pm 0.09$ \\
\hline \multicolumn{2}{|l|}{ Previous immunosuppressive medications \% (n) } \\
\hline Prednisone & $91.3(21)$ \\
\hline Methylprednisolone & $52.2(12)$ \\
\hline Cyclophosphamide & $8.7(2)$ \\
\hline Azathioprine & $26.1(6)$ \\
\hline Cyclosporine & $13.0(3)$ \\
\hline Mycophenolate mofetil & $34.8(8)$ \\
\hline Hydroxychloroquine & $91.3(21)$ \\
\hline Number of previous immunosuppressive agents, mean \pm SD & $3.4 \pm 1.5$ \\
\hline \multicolumn{2}{|l|}{ Medication concomitant with rituximab \% (n) } \\
\hline Prednisone & $65.2(15)$ \\
\hline Cyclophosphamide & $26.1(6)$ \\
\hline Hydroxychloroquine & $91.3(21)$ \\
\hline IVIG & $13.0(3)$ \\
\hline Methylprednisolone & $17.4(4)$ \\
\hline $\begin{array}{l}\text { Number of immunosuppressive agents concomitant with } \\
\text { rituximab, mean } \pm \text { SD }\end{array}$ & $2.3 \pm 1.0$ \\
\hline \multicolumn{2}{|l|}{ Dose of prednisone, mean $\pm \mathrm{SD} \mathrm{mg} /$ day } \\
\hline Before rituximab & $26.2 \pm 15.5$ \\
\hline With rituximab & $56.0 \pm 21.3$ \\
\hline After rituximab & $14.8 \pm 15.3$ \\
\hline \multicolumn{2}{|l|}{ Rituximab regimen $\%(\mathrm{n})$} \\
\hline $4 \times 375 \mathrm{mg} / \mathrm{m}^{2}$ & $43.5(10)$ \\
\hline $2 \times 1 \mathrm{~g}$ & $30.4(7)$ \\
\hline Others & $26.1(6)$ \\
\hline
\end{tabular}

Method We analysed retrospectively the data of resistant SLE patients who received Rituximab

Results Data included 23 refractory SLE patients that received Rituximab which was indicated for lupus nephritis 26.1\%, haematological involvement $21.7 \%$, neuropsychiatric complications $30.4 \%$, cutaneous involvement $13.0 \%$, and combination of lupus nephritis and haematological involvement $8.6 \%$. Mean \pm SD of SELENA Modified version - SLEDAI score at baseline was $15.0 \pm 8.8$ and $9.2 \pm 9.0$ at 6 months after treatment (p value. 002). Among patients with lupus nephritis Complete renal response was noted in $2(8.7 \%)$ out of 8 patients. Partial response was documented in 3 (13.0\%). 3 of 7 patients with haematological involvement responded completely, 2 have responded partially the other 2 did not respond to Rituximab. $5(21.7 \%)$ patients of 7 neuropsychiatric patients showed complete response, and no response was noted in $2(8.7 \%)$ patients. 4 out of 5 , who showed complete response undergone remission. Two non-responders eventually died. Only $3(13.0 \%)$ patients showed cutaneous involvement. 2 of them showed partial response and remaining 1 showed complete response. Adverse effects were noted in 8 (34.8\%) patients. $2(8.7 \%)$ of them reported acute infusion reaction, 4 $(17.4 \%)$ showed features of severe infection and 2 (8.7\%) patients died due to septic shock and multi organ failure (table 3).

Conclusion Rituximab is an effective and relatively safe agent for refractory SLE, additional well-structured controlled studies are needed to prove efficacy in those patients compared to other conventional therapy.

\section{PS7:140 BELIMUMAB IN SYSTEMIC LUPUS ERYTHEMATOSUS. 1 YEAR OF FOLLOW UP}

V Aldasoro Cáceres, M Varela García, J Mendizabal Mateos, L Garrido Courel, C Fito Manteca, N del Val del Amo, R Gutiérrez Polo, I Paniagua Zudaire, L Horcada Rubio, R Ibáñez Bosch, E Loza Cortina. Complejo Hospitalario de Navarra, Pamplona, Spain

\subsection{6/lupus-2018-abstract. 183}

Objectives To describe patients with Systemic Lupus Erythematosus (SLE) treated with Belimumab (BLM).

Material and methods Review of patients with SLE treated with BLM from 2012 to 2017.

Results We enrolled 18 patients, 16 women and 2 men. The median age at of SLE diagnose was 34.3 (IQR 27-45.7) years and the median age at BLM start was 2.2 (IQR 38.9-47) years. The received sDMARDs median number was 2.5 (IQR 2-4). Before starting BLM 7 patients had received rituximab, 4 cyclophosphamide, 1 abatacept and 1 one efalizumab. At BLM begin 17 patients were taking prednisone, 13 hydroxycloroquine, 7 methotrexate, 1 azatioprine, 1 mycophenolate and 1 leflunomide (table 1).

The median BLM bolus received was 8.5 (IQR 2-32.7) and it was stopped in 4 patients due to lack of efficacy; this 4 patients had persistence of arthritis and non of them had received bDMARD before.

13 patients had at least one antiphospholipid autoantibody positive and 4 developed antiphospholipid syndrome.

The median titer of antinuclear antibodies (ANA) was 1/ 360 (IQR 1/160-1/1280). All patients but one had ANA positive; among them 9 patients were antiRo positive, 4 antiLa, 4 antiSm and 4 antiRNP positive antibodies. 9 patients were antiDNA positive and 5 were positive for rheumatoid factor (RF) able 1 shows SLEDAI, C3 and C4, antiDNA levels. 